\title{
Molecular identification of Trypanosoma brucei brucei and in vitro anti-trypanosomal activity of different parts of methanolic extract of Senna occidentalis
}

\author{
Zainab Aliyu Alhafiz ${ }^{*}$ (D) Mohammed Sani Abdulsalami ${ }^{2}$, Mohammed Auwal Ibrahim ${ }^{3}$, Timothy Bulus ${ }^{4}$ and \\ Ahmed Babangida Suleiman ${ }^{5}$
}

\begin{abstract}
Objective: The present study investigated the anti-Trypanosoma brucei brucei activity of methanolic extract of Senna occidentalis roots, leaves, stem bark, and seed in vitro and bioactive components of the most active plant part.

Materials and methods: Trypanosoma brucei brucei was identified by PCR, cultured in Dulbecco's Modified Eagle Medium (DMEM) and incubated at $37^{\circ} \mathrm{C}$ and $5 \% \mathrm{CO}_{2}$. Subsequently, the cultured T. brucei brucei were incubated with $500 \mu \mathrm{g} / \mathrm{ml}$ concentration of different parts of $S$. occidentalis plant and the most potent fraction was identified and subjected to Gas Chromatography-Mass Spectrometry (GC-MS).

Results: Amplicons of the rRNA gene of T. brucei brucei detected had a size of $1200 \mathrm{bp}$. The anti-trypanosomal activities indicated that the root extract of the plant was the most active at $500 \mu \mathrm{g} / \mathrm{ml}$ with inhibitory activity of $88.89 \%$ and fractions ( 2 and 5 ) the most active with $\mathrm{IC}_{50}$ values of 1.49 and $1.16 \mu \mathrm{g} / \mathrm{ml}$ respectively.

Conclusion: Results from this study insinuates that phenolic and simple aliphatic compounds might play key role in the anti-trypanosomal activity of S. occidentalis roots.
\end{abstract}

Keywords: Senna occidentalis, Anti-trypanosomal activity, Polymerase chain reaction, Trypanosoma brucei brucei, Gas chromatography-mass spectrometry

\section{Introduction}

African trypanosomiasis has been estimated to render 50 million people and 48 million cattle at risk leading to low productivity and death [1]. The disease is responsible for major health and economic problems in rural sub-Saharan Africa and caused mainly by an extracellular protozoa belonging to the genus, Trypanosoma with species such as Trypanosoma brucei brucei [2].

Treatment option using vaccine is difficult owing to antigenic variation exhibited by the parasite and as such,

\footnotetext{
* Correspondence: zainabalhafiz80@gmail.com

1 Department of Biochemistry, Faculty of Science, Federal University Gusau,

Gusau, Zamfara State, Nigeria

Full list of author information is available at the end of the article
}

majority of the treatment against the disease are basically therapeutic and prophylactic. However, the available drugs for the treatment of trypanosomiasis are toxic, expensive, difficult to administer, less effective, cause severe adverse reactions, and face the problem of drug resistance $[3,4]$. Due to these shortcomings, it is imperative to explore more effective plant-derived therapeutic agents against African animal trypanosomiasis. This is because the search for effective, less toxic, cheaper plant-derived drugs for the treatment of animal trypanosomiasis is growing and is being encouraged, particularly in developing countries of the world, where orthodox medicines are usually too expensive for the majority of the population [5]. In fact, approximately $80 \%$ of the

\section{Springer Open}

(c) The Author(s). 2020 Open Access This article is licensed under a Creative Commons Attribution 4.0 International License, which permits use, sharing, adaptation, distribution and reproduction in any medium or format, as long as you give appropriate credit to the original author(s) and the source, provide a link to the Creative Commons licence, and indicate if changes were made. The images or other third party material in this article are included in the article's Creative Commons licence, unless indicated otherwise in a credit line to the material. If material is not included in the article's Creative Commons licence and your intended use is not permitted by statutory regulation or exceeds the permitted use, you will need to obtain permission directly from the copyright holder. To view a copy of this licence, visit http://creativecommons.org/licenses/by/4.0/. 
world population uses traditional medicine for primary health care and medicinal plants have been very instrumental to pharmaceutical drug discovery and industry [6].

Senna occidentalis (L.) Link, formally known as Cassia occidentalis L. [7], is a member of the Senna genus and belongs to the family Fabaceae. It is a wild flowering plant found in many tropical countries with roots, leaves, flowers, and seeds used in herbal medicine around the world. Extracts of different parts of the plant are known to have antidiabetic [8], analgesic [9], antibacterial [10]), antipyretic [9], antianxiety and antidepressant activities [11]. The plant extract was also proven to have effective antimalarial [12-14], anti-inflammatory [15] and antioxidant /hepatoprotective activities [16, 17].

Based on a previous report [18], the crude extract of the leaves of $S$. occidentalis demonstrated in vitro activity against T. brucei brucei and caused a complete cessation of parasites' motility within $10 \mathrm{~min}$ post incubation. Furthermore, the extract also showed in vivo anti-trypanosomal activity and consequently ameliorated trypanosome-induced anaemia, hepatomegaly and splenomegaly in infected rats. However, the in vitro screening of the plant in the study involves counting the parasites at $10 \mathrm{~min}$ interval for $1 \mathrm{~h}$ which might not be adequate for drug-parasite interaction. Moreover, microscopy was used to detect the T. brucei brucei which cannot effectively eliminate the presence of other species of trypanosomes in addition to other inherent limitations of the basic microscopy. Therefore, in the present study, PCR was used to detect the presence of the T. brucei brucei DNA in the blood of infected rats. Additionally, other parts of the plant have not been investigated for the anti-trypanosomal activity and possible bioactive antitrypanosomal components have not been identified. Hence, this study was designed to evaluate the in vitro anti-trypanosomal efficacy of the methanolic root, leaf, seed and stem bark extracts in addition to the molecular identification of the parasite and identification of bioactive antitrypanosomal agents.

\section{Materials and methods}

\section{Chemicals and reagents}

Sodium dihydrogen phosphate, disodium hydrogen phosphate, methanol, ethyl acetate, glucose, HEPES salt, Ethylene diamine tetraacetic acid (EDTA), ethidium bromide, were products of British Drug House (BDH) Chemicals Ltd., Poole England, Dulbecco Minimum Essential Medium (DMEM) from Sigma Chemical Company (USA), diminal ${ }^{\circ}$ from Eagle Chemical Company LTD, Ikeja, Nigeria, Silica Gel 60-200 mesh was from Qualikems fine Chem Pvt. Ltd., India, Silica gel coated Aluminum TLC plates 60F254 were products of Merck. India.

\section{Plant collection and extraction}

Senna occidentalis leaves were collected from farmlands in Unguwan Rimi, Kaduna State. The plant was identified and authenticated at the herbarium in the Department of Biological Science, Nigeria Defence Academy, Kaduna and voucher number issued (voucher number: 1627). Plant leaves were air dried at room temperature $\left(28^{\circ} \mathrm{C}-30^{\circ} \mathrm{C}\right)$ and stored in air-tight polythene bags. A total of $135 \mathrm{~g}$ of powdered S. occidentalis root, $150 \mathrm{~g}$ of $S$. occidentalis leaves, $55 \mathrm{~g}$ of $S$. occidentalis stem bark and $200 \mathrm{~g}$ of $S$. occidentalis seeds were weighed and individually soaked in $350 \mathrm{ml}$ absolute methanol. This was shaken intermittently and left for 72 $\mathrm{h}$. The solvent was decanted and filtered using Whatman filter paper No .1. The respective extracts were then concentrated using a rotary evaporator (Model RE52A, China) at $40^{\circ} \mathrm{C}$.

\section{Trypanosome parasites}

Trypanosoma brucei brucei (Federe strain) was obtained from Nigerian Institute for Trypanosomiasis and Oncocerciasis Research (NITOR), Kaduna state. Parasites were harvested at peak parasitemia $\left(10^{9}\right.$ parasites $\left./ \mathrm{ml}\right)$ from the blood of a donor rat, grown in healthy laboratory white albino rats and maintained in the laboratory by serial passage in rats.

At peak parasitemia, the rat was sacrificed and blood collected by cardiac puncture into EDTA container. Phosphate buffer saline was added in the ratio of 1:1 and centrifuged at $4000 \mathrm{rpm}$ for $10 \mathrm{~min}$. The buffy coat layer and portion slightly above the buffy coat layer was collected and centrifuged at $8000 \mathrm{rpm}$ for $5 \mathrm{~min}$. The supernatant was discarded leaving behind the concentrated parasite suspension.

\section{Extraction of DNA from concentrated T. brucei brucei suspension and PCR detection}

Trypanosome DNA extraction was carried out according to the instruction of GeneJET genomic DNA extraction kit (Thermo Scientific, Germany). Briefly, $200 \mu \mathrm{l}$ of parasite suspension was lysed by adding $400 \mu \mathrm{l}$ of HEPEStriton lysis buffer solution and $10 \mu \mathrm{l}$ of proteinase $\mathrm{K}$ and vortexed to obtain a homogenous suspension. These were incubated at $65^{\circ} \mathrm{C}$ for $1 \mathrm{~h}$ with vortexing after every $20 \mathrm{~min}$. Thereafter, $400 \mu \mathrm{l}$ of phenol-chloroform was added to the prepared lysate, vortexed for $15 \mathrm{~s}$ and centrifuged at $14,000 \mathrm{rpm}$ for $10 \mathrm{~min}$. Supernatant was removed into another tube followed by the addition of $1000 \mu \mathrm{l}$ absolute ethanol and $40 \mu \mathrm{l}$ of $3 \mathrm{M}$ sodium acetate. The tube was inverted and incubated overnight at $20^{\circ} \mathrm{C}$ followed by a subsequent centrifugation at 14000 rpm for $10 \mathrm{~min}$ and the supernatant was discarded. Then, $400 \mu \mathrm{l}$ of $70 \%$ ethanol was added and supernatant once again discarded. The eluent of DNA collected was air dried and $50 \mu \mathrm{l}$ of deionized water was added. Finally, the DNA collected in the micro-centrifuge tube was stored at $-20{ }^{\circ} \mathrm{C}$ until needed for processing. 
The PCR detection of the parasites was conducted based on the ITS-1 primer sets to validate the presence of trypanosome DNA. The forward and reverse primers used were CCG GAA GTT CAC CGA TAT TG and TTG CTG CGT TCT TCA ACG AA respectively. The PCR was carried out in a final volume of $11 \mu \mathrm{l}$ containing $4 \mu \mathrm{l}$ phusion flash high fidelity PCR master mix, $1 \mu \mathrm{l}$ each of forward and reverse primers, $2 \mu$ of extracted DNA and $3 \mu \mathrm{l}$ of PCR grade water. Initial denaturation at $98^{\circ} \mathrm{C}$ for $30 \mathrm{~s}$, denaturation at $98^{\circ} \mathrm{C}$ for $10 \mathrm{~s}$, annealing at $52^{\circ} \mathrm{C}$ for $30 \mathrm{~s}$, extension at $72{ }^{\circ} \mathrm{C}$ for $30 \mathrm{~s}$ and final extension at $72{ }^{\circ} \mathrm{C}$ for $10 \mathrm{~min}$ were employed. At the end of the PCR, the product was electrophoresed through $2 \%$ agarose containing $0.5 \mu \mathrm{g} / \mathrm{ml}$ ethidium-bromide and the voltage was set at $60 \mathrm{~V}$ for $30 \mathrm{~min}$. The product was visualized using a gel documentation system (Gel-Doc 2000, Bio-Rad).

\section{In vitro cultivation of Trypanosoma brucei brucei}

Cultivation of the prepared T. brucei brucei was initiated by placing $6.6 \times 10^{6}$ parasites $/ \mathrm{ml}$ parasite density in a test tube containing $5 \mathrm{ml}$ of DMEM supplemented with $10 \%$ horse serum, $25 \mathrm{mM}$ HEPES salt, and $0.1 \%$ glucose. This was maintained at $37^{\circ} \mathrm{C}$ using $5 \% \mathrm{CO}_{2}$ in an incubator for 6 hrs. The parasites were counted using a New Improved Neubauer counting chamber [19] and the parasite density was calculated using the formula below:

Density $($ cells $/ \mathrm{ml})=$ Number counted $\times 50 \times 1000 \times$ Dilution Factor employed.

In vitro study with methanolic crude extracts of different parts Senna occidentalis

Exactly $500 \mu \mathrm{g} / \mathrm{ml}$ of the methanol extract from different parts of S. occidentalis plant (leaves, stem bark, roots and seeds) were incubated with cultured T. brucei brucei. For each experiment, $50 \mu \mathrm{l}$ of parasite suspension $\left(1.6 \times 10^{6}\right.$ parasites $\left./ \mathrm{ml}\right)$ and $50 \mu \mathrm{l}$ of the extract were dispensed into $100 \mu \mathrm{l}$ of the constituted medium in wells of microtitre plates and incubated in a $\mathrm{CO}_{2}$ incubator for $1 \mathrm{~h}$. Wells containing $50 \mu \mathrm{l}$ of standard drug (diminal ${ }^{\circ}$ ) instead of plant extract served as the positive control while those containing no plant extract served as negative control. The parasite density was determined every hour for the period of $6 \mathrm{~h}$.

\section{In vitro anti-trypanosomal activity of root extract of S.occidentalis}

Based on the results of the above experiment, different concentrations $(1,10,50,100,500,1000$ and $2000 \mu \mathrm{g} / \mathrm{ml})$ of the root extract that had the best activity were incubated with cultured T. brucei brucei and the parasite density was calculated as described earlier.

\section{Column chromatography of Methanolic extract of $S$.} occidentalis root

A column $(30 \times 4 \mathrm{~cm})$ was packed with $100 \mathrm{~g}$ of silica gel (mesh size 60-200) to a height of $12 \mathrm{~cm}$. About $5 \mathrm{~g}$ of the extract was dissolved in small amount of methanol then mixed with a small amount of activated sand and allowed to dry. The dried mixture was gently loaded on the packed column which was eluted with $100 \%$ ethyl acetate, ethyl acetate: methanol (2:1), ethyl acetate: methanol (1:1), and ethyl acetate: methanol (1:2) as the mobile phase. One hundred fractions were collected in $50 \mathrm{ml}$ aliquots at a flow rate of $3 \mathrm{ml} / \mathrm{min}$. The contents of the fractions were examined by TLC and fractions with similar TLC pattern were pooled together into five fractions labelled fraction 1,2,3,4 and 5. Different concentrations $(1-2000 \mu \mathrm{g} / \mathrm{ml})$ of each fraction was incubated with the cultured T. brucei brucei and screened for anti-trypanosomal activity as described earlier. The most active fractions were further subjected to gas chromatography- mass spectrometry analyses.

\section{Gas chromatography- mass spectrometry analyses}

The GC-MS analysis of fractions 2 and 4 were conducted with an Agilent 6890 N GC interfaced with double-focusing 5973 mass spectrometer (MS). Helium was used as the carrier gas with a flow rate of $1.0 \mathrm{ml} /$ min and a linear velocity of $37 \mathrm{~cm} / \mathrm{s}$. The MS operating conditions were: Ionization voltage of $70 \mathrm{eV}$ and ion source of $250^{\circ} \mathrm{C}$. The GC was fitted with a $30 \mathrm{~m} \times 0.32$ $\mathrm{mm}$ fused capillary silica column coated with DB-5. Identification of the compounds was done by comparing retention indices, matching fragmentation patterns and mass spectral data with those in the National Institute of Standards and Technology (NIST) library.

\section{Statistical analysis}

All experiments were carried out in three replicates. Data were analyzed with a statistical software package (SP for Windows, version 18, IBM Corporation, NY, USA) using Tukey's-HSD multiple range post-hoc test. Values were considered significantly different at $P<0.05$.

\section{Results \\ PCR detection of Trypanosoma brucei brucei}

The PCR detection based on ITS-1 primer sets detected the presence of T. brucei brucei DNA in the blood of infected rats as shown in Fig. 1. The T. brucei brucei PCR product was approximately $1200 \mathrm{bp}$.

Percentage yield and in vitro anti-trypanosomal activity of methanolic extracts of different parts of Senna occidentalis

The yield and anti-trypanosomal activity of different parts of $S$. occidentalis extracted with methanol is 


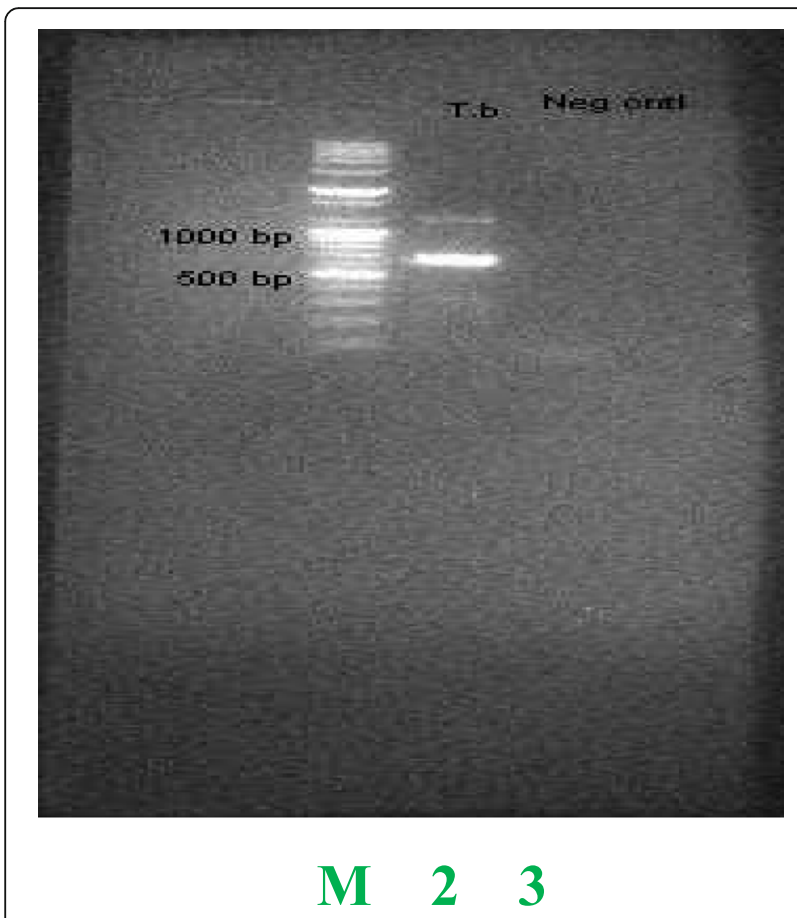

Fig. 1 Amplicons of the rRNA gene of T. brucei brucei with a size of 1200 bp. Lane 2 (ITS 1), Lane 3 (Negative control), M=a 100 bp ladder served as size marker

presented in Table 1. The leaves and stem bark of S. occidentalis showed a higher yield compared to the roots and seed. The anti-trypanosomal activities indicated that the root extract at $500 \mu \mathrm{g} / \mathrm{ml}$ produced highest inhibitory activity $(88.89 \%)$ against the parasites than other extracts while for diminazine aceturate $(50 \mu \mathrm{g} / \mathrm{ml})$, trypanosomes were not detectable for the $5 \mathrm{~h}$ experimental duration. Hence, the root extract was selected for further studies.

\section{In vitro anti-trypanosomal activities of different} concentrations of Methanolic extracts of S. occidentalis roots From Fig. 2, the results for the in vitro anti-trypanosomal activity of different concentrations of the root fractions showed $100 \%$ inhibition at concentration of $500 \mu \mathrm{g} / \mathrm{ml}$ while $100 \mu \mathrm{g} / \mathrm{ml}$ was found to have $74.55 \%$ inhibition after $6 \mathrm{~h}$ incubation. The standard drug, diminazine aceturate showed complete inhibition at a concentration of $50 \mu \mathrm{g} / \mathrm{ml}$ (data not shown).

Table 1 Percentage yield and in vitro anti-trypanosomal activity of different parts of Senna occidentalis

\begin{tabular}{lll}
\hline $\begin{array}{l}\text { Methanolic Extracts of } \\
\text { different plant parts }\end{array}$ & \% Yield & $\begin{array}{l}\text { \% inhibition of } \\
\text { T.brucei brucei }\end{array}$ \\
\hline Senna occidentalis Leaves & 10.30 & 38.89 \\
Senna occidentalis Stem bark & 6.58 & 58.33 \\
Senna occidentalis Roots & 3.28 & 88.89 \\
Senna occidentalis Seeds & 3.28 & 58.33 \\
\hline
\end{tabular}

Moreover, of the five fractions tested, fractions 2 and 5 demonstrated excellent anti-trypanosomal activity with $\mathrm{IC}_{50}$ of 1.49 and $1.16 \mu \mathrm{g} / \mathrm{ml}$ respectively against $T$. brucei brucei while fractions 1,3 and 4 exhibited lower antitrypanosomal activity with $\mathrm{IC}_{50}$ of $5.65,2.83$ and $2.72 \mu \mathrm{g} /$ $\mathrm{ml}$ respectively (Table 2 ).

\section{GC-MS analysis}

The most active fractions (2 and 5 showed a number of compounds from the GC chromatogram which were identified from the NIST library and presented in Tables 3 and 4. The compounds comprised mainly oxygenated and aromatic hydrocarbons.

Fraction 2 contained aromatic hydrocarbon comprising of cyclohex-3-enyl methyl heptyl ester, hydrocarbon (cyclohexyl methyl ester, cyclo hex-3-enyl methyl propyl ester, cyclo hex-3-enyl methyl hexyl ester, tricyclo $\{4.3 .1 .1(3,8)\}$ undecan-1-amine and predominantly furan-2-yl-(2,2,4-trimethyl-4-phenyl-3,4-dihydo-2H-quinolinyl)-methanone containing phenols with percentage peak area of 22.22.

Fraction 4 showed the presence of mainly aromatic hydrocarbons such as (di \{cyclo hex-3-enylmethyl\} ester, tricyclo $\{4.3 .1 .1(3,8)\}$ undecan-1-amine, Cyclo hex-3-enyl methyl hexyl ester, oxygenated hydrocarbons like $(2 \mathrm{H}$ pyrrol-2-one, N-(3-trifluoro methyl benzyl)-2-(4-methyl$4 \mathrm{H}-1,2,4-$ triazol-3-yl thio)-octa decanedioic acid and predominantly 10-chloro-2-methyl-2 azatricyclo $\{4.3 .1 .0(3,8)\}$ decane with high percentage peak area of 17.55 .

\section{Discussion}

Previous studies demonstrated the in vitro antitrypanosomal effects of only the leaves of S. occidentalis extract against T. brucei brucei within the span of $1 \mathrm{~h}$ [18], however the root, seed and stembark extracts have not been evaluated. In this current study, we evaluated the in vitro anti-T. brucei brucei activity of leaf, root, seed and stembark extracts of $S$. occidentalis within the period of 6 $\mathrm{h}$ allowing for sufficient drug-parasite interaction. Subsequently, the most active extract was also fractionated and further investigated for bioactive agent(s).

Unlike microscopy which cannot effectively eliminate the presence of other species of trypanosomes, this study employed identification of T. brucei brucei using PCR detection based on ITS primer which eliminates the presence of other species of trypanosomes [20, 21]. This finding detected $1200 \mathrm{bp}$ amplicon size of the rRNA gene in T. brucei brucei which agrees with Ahmed et al. [22] who identified same species of trypanosomes using ITS primer.

Although reports of Ibrahim et al. [18] showed that crude ethanolic extract of $S$. occidentalis leaves exhibited anti-trypanosomal activity against $T$. brucei brucei as it completely eliminated the parasites' motility within 10 min post incubation with $6.6 \mathrm{mg} / \mathrm{ml}$ of effective extract 


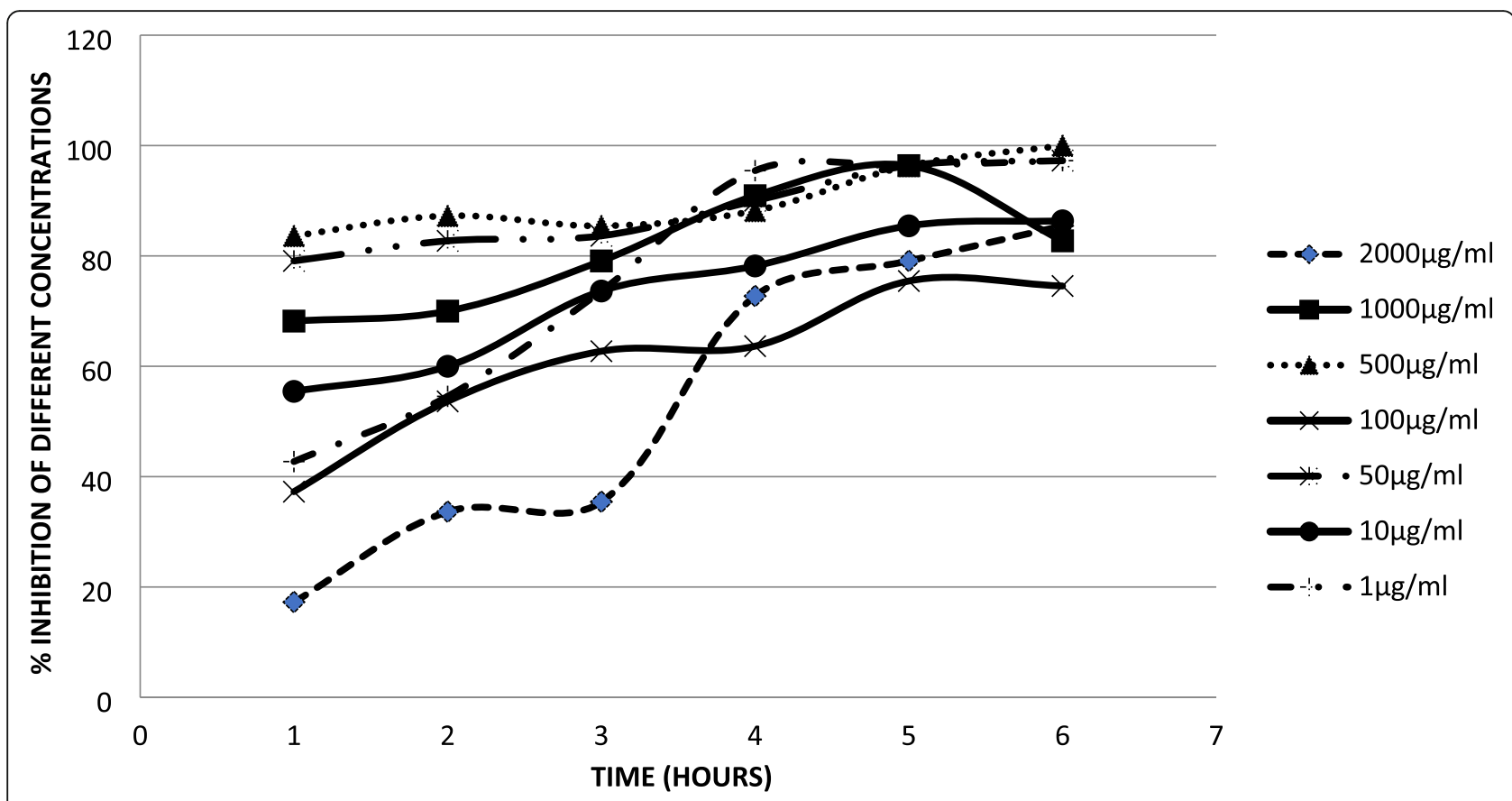

Fig. 2 In vitro effect of different concentrations of methanolic extract of S.occidentalis roots on percentage inhibition of T. brucei brucei

concentration, this study showed $100 \%$ and $74.55 \%$ inhibition after $6 \mathrm{~h}$ incubation at $500 \mu \mathrm{g} / \mathrm{ml}$ and $100 \mu \mathrm{g} / \mathrm{ml}$ concentration of root extract respectively. The disparity in anti-trypanosomal activities among the different parts could be due to differences in concentration and composition of bioactive constituents present in the plant part which is responsible for the separate roles they play in the plant.

While the previous reports of Ibrahim et al. [18], employed shorter time $(1 \mathrm{~h})$ for the studies, this investigation involved the cultivation of trypanosome in vitro for longer period of time $(6 \mathrm{~h})$ in order to allow for adequate drug-parasite interaction, thereby avoiding wrong or misleading interpretations. Our selection of the root extract for subsequent study was based on the classification according to Bero et al. [23] where extract with $\mathrm{IC}_{50}<20 \mu \mathrm{g} /$ $\mathrm{ml}$ and $\mathrm{IC}_{50}>100 \mu \mathrm{g} / \mathrm{ml}$ are considered very good and ineffective, respectively. Owing to this classification, result from the present study of the methanolic extract of S. occidentalis root with $\mathrm{IC}_{50}$ of $18 \mu \mathrm{g} / \mathrm{ml}$ suggest that the extract have a good anti-trypanosomal activity. Prior to this study,

Table 2 IC 50 T. brucei brucei of various fractions tested

\begin{tabular}{ll}
\hline Fractions tested & $\mathrm{IC}_{50}$ T.brucei brucei $(\mathrm{\mu g} / \mathrm{ml})$ \\
\hline Fraction 1 & 5.65 \\
Fraction 2 & 1.49 \\
Fraction 3 & 2.83 \\
Fraction 4 & 2.72 \\
Fraction 5 & 1.16 \\
\hline
\end{tabular}

no attempt has been done to demonstrate the in vitro activities of methanolic extract of $S$. occidentalis root against T. brucei brucei.

The observed in vitro anti-trypanosomal activity of fractions of $S$. occidentalis methanolic root extract is not astounding owing to a report Ibrahim et al. [18] which demonstrated that ethanolic leaf extract of the plant possessed anti-trypanosomal activity. Using $\mathrm{IC}_{50}$ as index for measuring anti-trypanosomal activity, fractions 2 and 5 exhibited excellent antitrypanosomal activity as opposed to the other three (3) fractions.

The GC-MS analysis of the fractions 2 and 5 identified a number of compounds. A total of 29 different chemical compounds were identified. Anti-trypanosomal activity of both fractions might be attributed to the presence of phenolic compounds which have been reported to show significant anti-trypanosomal activity as reported by Oluwatosin and Clement [24] and Ibrahim et al. [25]. The predominant phenolic compound detected in fraction 2 is furan-2-yl-(2,2,4-trimethyl-4phenyl-3,4-dihydo-2H-quinolinyl)-methanone. Additionally, 8-azabicyclo $\{3.2 .1\}$ oct-2-ene in the fractions can also be attributed to the anti-trypanosomal activity of the fractions owing to the reports of Oluwatosin and Clement [24] in which simple aliphatic compounds were observed to possess anti-trypanosomal property in vivo. Therefore, it could be concluded that the aforementioned bioactive compounds present in the methanolic root extract of $S$. occidentalis might be responsible for its anti-trypanosomal activity in vitro. 
Table 3 Bioactive components identified in fraction 2 of methanol root extract of $S$. occidentalis by GC-MS

\begin{tabular}{llll}
\hline S/NO & Compounds & $\begin{array}{l}\text { Retention } \\
\text { time }\end{array}$ & $\begin{array}{l}\text { Peak area } \\
(\%)\end{array}$ \\
\hline 1 & Bicyclo \{3.3.1\} nonan-2-one & 33.358 & 1.69 \\
2 & Tricyclo \{4.3.1.1 (3,8)\} undecan-1-amine & 25.964 & 3.86 \\
3 & 8-azabicyclo \{3.2.1\} octane-3,6-diol & 29.227 & 1.46 \\
4 & Cyclohex-3-enyl methyl heptyl ester & 29.901 & 6.31 \\
5 & 2H-pyrrol-2-one & & 0.88 \\
6 & 8-azabicyclo $\{3.2 .1\}$ oct-2-ene & 31.646 & 1.63 \\
7 & Glycidyl palmitate & 31.859 & 3.80 \\
8 & Fumaric acid & 31.846 & 2.73 \\
9 & Cyclo hex-3-enyl methyl hexyl ester & 33.719 & 5.61 \\
10 & Cyclo hex-3-enyl methyl propyl ester & 33.390 & 5.61 \\
11 & Furan-2-yl-(2,2,4-trimethyl-4-phenyl-3,4- & 34.10 & 22.22 \\
& dihydo-2H-quinolinyl)-methanone & & \\
12 & Cyclohexyl methyl ester & 34.346 & 3.64 \\
13 & Glutaric acid & 29.942 & 2.97 \\
\hline
\end{tabular}

Table 4 Bioactive components identified in fraction 4 of methanol root extract of S. occidentalis by GC-MS

\begin{tabular}{|c|c|c|c|}
\hline $\mathrm{S} / \mathrm{NO}$ & Compound & $\begin{array}{l}\text { Retention } \\
\text { time }\end{array}$ & $\begin{array}{l}\text { Peak area } \\
(\%)\end{array}$ \\
\hline 1 & Bicyclo $\{3.3 .1\}$ nonan-2-one & 26.321 & 1.69 \\
\hline 2 & Camphor-10-sulfonic acid & 29.591 & 3.96 \\
\hline 3 & 2H-pyrrol-2-one & 29.591 & 3.96 \\
\hline 4 & Fumaric acid & 29.841 & 4.01 \\
\hline 5 & Di (cyclohex-3-enyl methyl) ester & 24.418 & 4.01 \\
\hline 6 & Glutaric acid & 29.942 & 2.04 \\
\hline 7 & $\begin{array}{l}\text { Cyclo hex-3-enyl) methyl cyclohexyl me- } \\
\text { thyl ester iso sativene }\end{array}$ & 29.942 & 2.04 \\
\hline 8 & Tricyclo $\{4 \cdot 3 \cdot 1.1(3,8)\}$ undecan-1-amine & 35.748 & 3.66 \\
\hline 9 & Cyclo hex-3-enyl methyl hexyl ester & 34.356 & 7.28 \\
\hline 10 & Cyclo hex-3-enyl methyl decyl ester & 30.476 & 2.31 \\
\hline 11 & Borazine & 30.325 & 2.23 \\
\hline 12 & Cyclo hex-3-enyl methyl heptyl ester & 34.259 & 2.73 \\
\hline 13 & Glycidyl palmitate & 31.850 & 3.75 \\
\hline 14 & $\begin{array}{l}\mathrm{N} \text {-(3-trifluoro methyl benzyl)-2-(4-methyl- } \\
4 \mathrm{H}-1,2,4-\text { triazol-3-yl thio)-octa decanedioic } \\
\text { acid }\end{array}$ & 31.850 & 3.75 \\
\hline 15 & Cyclo hex-3-enyl methyl ester & 30.195 & 1.20 \\
\hline 16 & Di (cyclo hex-3-enyl methyl) ester & 33.733 & 2.97 \\
\hline 17 & 8-azabicyclo $\{3.2 .1\}$ octan-3-ol & 34.092 & 3.26 \\
\hline 18 & 8-azabicyclo $\{3.2 .1\}$ octan-3,6-diol & 34.092 & 3.26 \\
\hline 19 & $\begin{array}{l}\text { 10-chloro-2-methyl-2-azatricyclo \{4.3.1.0 } \\
(3,8)\} \text { decane }\end{array}$ & 34.092 & 17.55 \\
\hline 20 & 19-cyclo-27-norlanostan-25-one & 35.491 & 0.88 \\
\hline
\end{tabular}

\section{Conclusions}

This study insinuates that the root of S. occidentalis has potent anti-trypanosomal activities and phenolic and simple aliphatic compounds might play key role in the anti-trypanosomal activity. However, further studies will investigate the in vivo anti-trypanosomal activity of the suggested bioactive compounds.

\begin{abstract}
Abbreviations
GC-MS: Gas chromatography- mass spectrometry; DMEM: Dulbecco's Modified Eagle Medium; ITS: Internal transcribed spacer; IC50: Half maximal Inhibitory concentration; PCR: Polymerase Chain Reaction; rRNA: Ribosomal ribonucleic acid; NIST: National Institute of Standards and Technology; EDTA: Ethylenediaminetetraacetic acid

\section{Acknowledgements}

Not applicable.

\section{Authors' contributions}

ZAA performed all the in vitro studies, analyzed and interpreted the data and was a major contributor in writing the manuscript. MSA performed cultivation of the prepared T. brucei brucei and preparation of the culture medium. MAI conducted the selection, collection and preparation of plant extract fractions and also contributed to the writing of the manuscript. TB carried out GC-MS analysis. ABS conducted part of the molecular identification of the parasite. All authors read and approved the final manuscript.
\end{abstract}

\section{Authors' information}

ZAA is Mrs. Zainab Aliyu Alhafiz, Lecturer, in Federal University Gusau, Zamfara State, Nigeria pursuing a PhD under the tutelage of Dr. MAl, in Ahmadu Bello University Zaria, Nigeria. MSA is Dr. Muhammed Sani Abdulsalami, Associate Professor, in Nigerian Defence Academy, Kaduna State, Nigeria with over 20 years of research experience. MAI is Dr. Mohammed Auwal Ibrahim, in Ahmadu Bello University Zaria, Nigeria with 15 years of research experience. TB is Dr. Timothy Bulus, in Kaduna State University, Kaduna State, Nigeria with over 15 years of research experience and ABS is Ahmed Babangida Suleiman, Associate Professor in Ahmadu Bello University Zaria, Nigeria with over 15 years of research experience.

\section{Funding}

This work was not funded by any funding body.

\section{Availability of data and materials}

All the data was analyzed with a statistical software package (SP for Windows, version 18, IBM Corporation, NY, USA) using Tukey's-HSD multiple range post-hoc test.

Ethics approval and consent to participate

Not applicable.

\section{Consent for publication}

Not applicable.

\section{Competing interests}

The authors declare that they have no competing interests.

\section{Author details}

'Department of Biochemistry, Faculty of Science, Federal University Gusau, Gusau, Zamfara State, Nigeria. '2Department of Biological Sciences, Nigerian Defence Academy, Kaduna, Nigeria. ${ }^{3}$ Department of Biochemistry, Ahmadu Bello University, Zaria, Nigeria. ${ }^{4}$ Department of Biochemistry, Kaduna State University, Kaduna, Nigeria. ${ }^{5}$ Department of Microbiology, Ahmadu Bello University, Zaria, Nigeria. 
Received: 30 October 2019 Accepted: 20 May 2020

Published online: 01 June 2020

\section{References}

1. World Health Organization A New form of Human Trypanosomiasis in India. Description of the First Human Case in the World Caused by Trypanosoma evansi. Weekly Epidemiol Record. 2005;80(7):62.

2. Adeyemi OS, Akanji MA, Johnson TO, Ekanem JT. Iron and nitric oxide balance in African trypanosomosis: is there really a link? Asian J Biochem. 2011;6:15-28.

3. Burri C. Chemotherapy against human African trypanosomiasis: is there a road of success? Parasitology. 2010;137:1987-94.

4. World Health Organization. Control and surveillance of human African Trypanosomiasis report of a WHO expert committee WHO technical report series 984. Geneva: World Health Organization; 2013.

5. Rasool Hassan BA. Medicinal plants (importance and uses). Pharmaceut Anal Acta. 2012;3:e139. https://doi.org/10.4172/21532435.1000e139.

6. Liu WJH. Traditional herbal medicine research methods: identification, analysis, bioassay, and pharmaceutical and clinical studies. Hoboken: Wiley; 2011. p. 477.

7. GBIF Global Biodiversity Information Facility (2011) Backbone Taxonomy, accessed from http://www.gbif.org/species on 15 Oct 2012

8. Laxmi V, Anirudh K, Basant K, Umesh K, Pand Rajesh SP. Antidiabetic activity of Cassia occidentalis (Linn) in normal and alloxan-induced diabetic rats. Indian J Pharmacol. 2010;42(4):224-8.

9. Sini KR, Sinha BN, Karpakavalli M, Sangeetha PT. Analgesic and antipyretic activity of Cassia occidentalis Linn. Ann Biol Res. 2011;2(1):195-200 37.

10. Chukwujewu JC, Coombes PH, Mulholland DA, Vanstaden J. Emordin, an antibacterial anthraquinone from the roots of Cassia occidentalis. S Afr J Bot. 2006;72:295-7.

11. Saba S, Srinath Reddy T, Arafath S, Nagarjuna S, Padmanabha Reddy $Y$. Evaluation of Antianxiety and Antidepressant activity Of Cassia occidentalis leaves. Asian J Pharmacol Clin Res. 2012:5(3):47-50 36.

12. Tona L, Cimanga RK, Mesia K, Musuamba CT, De Bruyne T, Apers S. In vitro antiplasmodial activity of extracts and fractions from seven medicinal plants used in the Democratic Republic of Congo. J Ethnopharmacol. 2004;93:2732.

13. Tona L, Mesia K, Ngimbi NP, Chrimwami B, Ahoka O, Cimanga K. In-vivo antimalarial activity of Cassia occidentalis, Morinda morindoides and Phyllanthus niruri. Ann Trop Med Parasitol. 2001;95:47-57.

14. Tona L, Ngimbi NP, Tsakala M, Mesia K, Cimanga K, Apers S. Antimalarial activity of 20 crude extracts from nine African medicinal plants used in Kinshasa Congo. J Ethnopharmacol. 1999;68:193-203.

15. Basri DF, Fan SH. The potential of aqueous and acetone extracts of galls of Quercus infectoria as antibacterial agents. Indian J Pharmacol. 2005;37(1): $26-9$

16. Jafri MA, Subhani MJ, Javed K, Singh S. Hepatoprotective activity of leaves of Cassia occidentalis against paracetamol and ethyl alcohol intoxification in rats. J Ethnopharmacol. 1999;66:355-61.

17. Kolhapure SA, Mitra WS. Meta-analysis of 50 phase III clinical trials in evaluation of efficacy and safety of liv. 52 in infective hepatitis. Med Update. 2004:12:51-61

18. Ibrahim MA, Aliyu AB, Sallau AB, Bashir M, Yunusa I, Umar TS. Senna occidentalis leaf extract possesses anti-trypanosomal activity and ameliorates the trypanosome induced anemia and organ damage. Pharm Res. 2010;2(3):175-80.

19. Turgeon ML. Clinical laboratory science the basics and routine techniques. Mosby-Elsevier; 2007. p. 263-75.

20. Desquesnes M, Dávila AMR. Applications of PCR-based tools for detection and identification of animal trypanosomes: a review and perspectives. Vet Parasitol. 2002;109:213-31.

21. Desquesnes M, McLaughlin G, Zoungrana A, Davila AM. Detection and identification of Trypanosoma of African livestock through a single PCR based on internal transcribed spacer 1 of rDNA. Int J Parasitol. 2001;31(5-6): 610-4.

22. Ahmed HA, Picozzi K, Wellburn SC, Macleod TE. A comparative evaluation of PCR- based methods for species-specific determination of African animal trypanosomes in Ugandan cattle. Parasites Vectors. 2013;6:316.

23. Bero J, Hannaert V, Chataigné G, Hérent MF, Quetin-Leclercq J. In vitro antitrypanosomal and antileishmanial activity of plants used in Beninin traditional medicine and bio-guided fractionation of the most active extract. J Ethnopharmacol. 2011;1372:998-1002.

24. Oluwatosin KY, Clement OB. Evaluation of essential oils composition of methanolic Allium sativum extract on Trypanosoma brucei infected rats. Res Pharmaceutical Biotechnol. 2011;3(2):17-21.

25. Ibrahim MA, Musa AM, Aliyu AB, Mayaki HS, Gideon A, Shahidul Islam M. Phenolics-rich fraction of Khaya senegalensis stem bark: anti-trypanosomal activity and amelioration of some parasite-induced pathological changes. Pharm Biol. 2013:51(7):906-13.

\section{Publisher's Note}

Springer Nature remains neutral with regard to jurisdictional claims in published maps and institutional affiliations.

\section{Submit your manuscript to a SpringerOpen ${ }^{\circ}$ journal and benefit from:}

- Convenient online submission

- Rigorous peer review

- Open access: articles freely available online

- High visibility within the field

- Retaining the copyright to your article

Submit your next manuscript at $\boldsymbol{\nabla}$ springeropen.com 